The key topics of the program include advocacy of a social worker; methods of social advocacy; organization of an advocacy campaign; and social advocacy as a tool for protecting the rights and liberties of citizens. The paper covers examples of practical works and self-study tasks suggested for broadening students' knowledge of the theoretical material.

It is indicated, that as a result of completing the course, future social workers will develop the following key competences: to select and apply various methods of social advocacy, to develop programs of advocacy campaigns; to apply knowledge in practical situations and make informed decisions; to initiate social changes aimed at improving social welfare.

Further research into determining the level of formation of knowledge and skills of advocacy by future social workers upon completion of the course "Technologies of Social Advocacy" would be of interest.

Key words social worker, social work, advocacy, social service of representation of interests, social advocacy technologies.

УДК 378.147

Олена Мартиненко

Сумський державний педагогічний університет імені А. С. Макаренка ORCID ID 0000-0002-8287-0573

Ярослав Чкана

Сумський державний педагогічний університет імені А. С. Макаренка ORCID ID 0000-0003-3667-3584

Ольга Удовиченко

Сумський державний педагогічний університет імені А. С. Макаренка ORCID ID 0000-0002-3401-3251

DOI 10.24139/2312-5993/2020.02/144-153

\title{
УПРАВЛІННЯ САМОСТІЙНОЮ РОБОТОЮ МАЙБУТНІХ УЧИТЕЛІВ МАТЕМАТИКИ У ВІРТУАЛЬНОМУ НАВЧАЛЬНОМУ СЕРЕДОВИЩІ ЧЕРЕЗ ВИКОРИСТАННЯ ЕЛЕКТРОННОЇ ВЕРСІЇ РОБОЧОГО ЗОШИТУ
}

У статті досліджено питання управління самостійною роботою студентів під час дистанційного навчання студентів фрізико-математичних фракультетів педагогічних університетів. Уточнено поняття самостійної роботи студентів під час дистанційного навчання. Виділено особливості математичних дисциплін, що впливають на планування та організацію самостійної роботи студентів. Запропоновано використання електронної версії робочого зошита з математичного аналізу для забезпечення самостійної роботи студентів в інформаційно-освітньому середовищі університету, показано доцільність та ефективність роботи за ним.

Ключові слова: самостійна робота студентів, дистанційне навчання, електронна версія робочого зошиту, математичні дисципліни.

Постановка проблеми. Якісна освіта $€$ тим фактором, що визначає економічний та соціальний розвиток сучасного суспільства. Однією 3 характерних її особливостей $\epsilon$ створення умов для вибору кожним студентом власної траєкторії навчання, що відповідає його потребам та професійним цілям і зумовлює особистісний розвиток. 
Дистанційна освіта $€$ однією з технологій самостійного навчання студентів, що дає можливість реалізувати доступ кожного до всіх рівнів освіти в будь-якій країні. Вона також є актуальною для всіх тих, хто не має змоги навчатися за класичними формами в закладах вищої освіти.

Організація освітнього процесу під час дистанційного навчання потребує не тільки активного використання різних інформаційних ресурсів, а й подальшого вдосконалення інформаційно-освітнього середовища як засобу для забезпечення безперервного доступу до необхідної інформації, розвитку культури раціонального мислення й отримання нових знань. У цьому контексті під інформаційно-освітнім середовищем будемо розуміти сукупність інформаційно-освітніх ресурсів, програмно-технічних і комунікативних засобів, а також принципів їх використання в освітній діяльності.

Актуальним напрямом педагогічних теорій $€$ дослідження процесу управління самостійною роботою студентів в умовах інформаційноосвітнього середовища під час дистанційного навчання. Це зумовлює необхідність перегляду підходів до вибору й оновлення форм самостійної роботи, дидактичних засобів та їх змістовного наповнення, а також відповідної технологічної підтримки.

Аналіз актуальних досліджень. Науково-педагогічні дослідження різних аспектів дистанційного навчання охоплюють питання, пов'язані 3 педагогічним супроводом самоосвіти, ефективним управлінням пізнавальною діяльністю студентів, розробкою відповідного дидактичного забезпечення (Ю.А. Дубровська, О.В. Мірзабекова, О.Г. Рахмєєва, Л. Н. Рулієне, О. П. Яхіна та ін.).

Аналіз наукової літератури показує, що самостійна робота студентів, як основна форма їх діяльності під час дистанційного навчання, набуває нового статусу. Т.Н. Захожа, І.А. Зимня, П.І. Підкасистий визначають самостійну роботу студентів як діяльність із засвоєння фундаментальних знань та вмінь навчально-дослідницької діяльності, формування загальних і професійних компетентностей в інформаційно-освітньому середовищі. Питанням ії організації присвячені наукові праці Є.Я.Голанта, С.І.Архангельського, М. О. Данілова, використання інформаційних технологій розглянуто в роботах Л. М. Базір, І.В.Дмітрієва, О.В.Захарової, В.С. Самсонова, методи дистанційного навчання $€$ предметом дослідження І. М. Власової, Т. А. Макарчук, Е. Б. Новікової, Л. М. Починаліної, а мережевих технологій Г. О. Желєзнякової, В. С. Новікова.

Однак, поза увагою науковців залишається питання дослідження особливостей управління самостійною роботою під час дистанційного навчання студентів певних спеціальностей, а саме майбутніх учителів математики.

Метою статті $\epsilon$ дослідження управління самостійною роботою студентів під час дистанційного навчання фундаментальних математичних 
дисциплін майбутніх учителів математики в педагогічних університетах через використання електронної версії робочого зошита.

Методи дослідження. Для вирішення поставлених задач використовувалися такі методи дослідження:

- теоретичні - аналіз психолого-педагогічної, науково-методичної, математичної й навчальної літератури, дисертаційних робіт із проблеми організації та управління самостійною роботою студентів в умовах дистанційного навчання, з методики викладання математики;

- емпіричні - аналіз і узагальнення досвіду організації самостійної роботи студентів, спостереження за ходом начального процесу, анкетування, аналіз результатів самостійної роботи студентів під час навчання математичних дисциплін.

Виклад основного матеріалу. Серед основних тенденцій розвитку сучасної освіти найбільш актуальними є ї̈ глобалізація, безперервність і комерціалізація, інформатизація освітнього середовища, інтеграція науки та освіти, підвищення ролі самоосвіти. Вони зумовлюють необхідність використання в освітньому процесі сучасних інформаційних технологій, зокрема, мережі Internet, що допомагають організувати самостійну роботу студента, зробити процес навчання більш творчим, орієнтованим на потреби майбутньої професії. Це, у свою чергу, приводить до необхідності перебудови самих засад організації всього навчального процесу, пошуку та впровадження інноваційних педагогічних методів і технологій викладання.

Інформаційно-комунікаційні технології, як елемент дистанційного навчання, сприяють забезпеченню самостійної роботи студентів у сучасному інформаційно-освітньому середовищі. Вони допомагають не тільки працювати з інформацією (отримувати, конструювати, обмінюватися тощо), але й надають можливість для створення системи оцінювання результатів навчання.

Дистанційне навчання розглядають як поетапний процес організації системи професійної підготовки фахівців, що включає такі компоненти, як цілі і принципи впровадження, зміст і методи навчання, форми та засоби навчання, з можливістю реалізації взаємозв'язку студента й викладача на відстані (Назарко, 2016).

Під дистанційними ми розуміємо навчальні технології, що в основному реалізуються через застосування інформаційнотелекомунікаційних мереж під час опосередкованої взаємодії тих, хто навчається, і тих, хто навчає.

До основних переваг використання технології дистанційної освіти в навчальному процесі можна віднести:

- інтерактивну взаємодію викладача та студента в режимі діалогу, який досить часто за формою є наближеним до аудиторного спілкування; - швидкий рух (обмін) навчальних матеріалів в електронному вигляді; 
- оперативний доступ до баз інформації, розміщених у мережі Інтернет;

- вибір власного темпу роботи з навчальним матеріалом;

- тестування знань у дистанційному режимі;

- проходження віртуального лабораторного практикуму;

- створення віртуальних груп для підтримки оперативної взаємодії між студентами, студентами та викладачем.

Успішне дистанційне навчання забезпечується, з одного боку, високою самодисципліною студентів під час роботи з інформацією, але, з іншого боку, воно потребує педагогічного супроводу їх навчальної діяльності. Тому ефективне використання технологій дистанційного навчання припускає педагогізацію інформаційно-освітнього середовища, яке все частіше використовують під час організації позааудиторної самостійної роботи студентів та їх науково-дослідної діяльності.

Дистанційне навчання потрібно будувати на основі попередньо створеного предметного інформаційно-освітнього середовища, що враховує специфіку дисципліни як науки та визначає сукупність педагогічних програмних засобів і навчально-методичного забезпечення навчального процесу з вивчення цієї дисципліни.

Для організації дистанційного навчання студентів у Сумському державному педагогічному університеті імені А.С. Макаренка використовується віртуальне навчальне середовище Moodle (Modular Object-Oriented Dynamic Learning Environment) - пакет модульного програмного забезпечення з відкритим кодом, призначений для створення курсів дистанційного навчання i web-сайтів. Ця програма управління дистанційним навчанням орієнтована на взаємодію між викладачем і студентом, вона також використовується для підтримки очних курсів. Moodle може бути встановленим на будь-який комп'ютер, що підтримує PHP і роботу із СУБД MySQL, PostgreSQL, M icrosoft SQL Server; програмне забезпечення є кросплатформним.

Система Moodle декларує такі принципи:

- adaпmивності: Moodle містить засоби, що постійно розвиваються без перебудови самої системи, та методи, які забезпечують індивідуалізацію навчання;

- довгостроковості: навчальна платформа відповідає розробленим стандартам щодо інформаційних навчальних систем і надає можливість вносити зміни до навчальних матеріалів без перепрограмування;

- доступності: дає можливість працювати дистанційно з будь-якого комп'ютера, підключеного до мережі Інтернет;

- економності: поширюється безкоштовно (Демонстрація можливостей Moodle).

У зв'язку з переходом до нової парадигми в навчанні змінюються вимоги до організації самостійної роботи, і більшою мірою до 
позааудиторної, яка опосередковано готує студентів до майбутньої самостійної професійної діяльності. Це, у свою чергу, зумовлює необхідність формувати у студентів особливе ставлення до такого виду навчально-пізнавальної діяльності, а задачею викладача $€$ оптимізація управління самостійною роботою студентів у цілому.

Самостійна робота студентів $€$ основою дистанційного навчання, якому властиві: паралельність (навчання здійснюється одночасно 3 відповідною професійною діяльністю); високий рівень мотивації; високий ступінь самоорганізації та дисципліни студентів; розвиток у них наполегливості й цілеспрямованості; самостійне вдосконалення вже набутих навичок і вмінь та формування нових. Одним із головних питань у цьому контексті $є$ питання про ступінь самостійності виконання навчальних завдань (Рошаль та Семенова, 2004).

Правильно організована самостійна робота студентів $\epsilon$ не тільки обов'язковою складовою навчального процесу, але й об'єктивною умовою формування їх пізнавальної, творчої активності, вона є вагомим чинником розвитку однієї з провідних рис особистості - самостійності. 3 іншого боку, це засіб, що забезпечує свідоме та міцне засвоєння знань з предмету й оволодіння прийомами самоосвіти, розвиває потребу в самостійному поповненні знань і створює передумови для застосування їх у майбутній професійній діяльності. Саме цей дидактичний потенціал самостійної роботи робить ії важливою складовою підвищення ефективності підготовки спеціалістів. Крім того, що робочими програмами кожної дисципліни передбачена досить велика частка самостійної роботи студентів під час вивчення кожної дисципліни, а сучасні реалії вимагають ще більшого її впровадження в навчальний процес та, як наслідок, удосконалення навчально-виховного процесу в ЗВО.

Під самостійною роботою студентів під час дистанційного навчання ми розуміємо систему набуття знань, що дозволяє використовувати можливості різноманітних дидактичних засобів та технологій дистанційного навчання з обґрунтуванням їх вибору; реалізовувати нові форми взаємодії викладача та студента; здійснювати пошук інноваційних методів навчання та запроваджувати новітні навчальні технології (Мартиненко та Чкана, 2017).

у процесі навчання студентів самостійна робота супроводжує всі етапи, які визначають логіку засвоєння певної дисципліни:

- постановка пізнавальної задачі та її усвідомлення;

- пошук навчального матеріалу в різних інформаційних джерелах;

- опрацювання отриманої навчальної інформації;

- засвоєння знань, формування вмінь, навичок і компетентностей, їх практичне застосування;

- перевірка рівня засвоєння знань та сформованості вмінь і компетентностей. 
Важливим аспектом організації самостійної роботи студентів під час дистанційного навчання $€$ створення чіткої системи контролю за ії виконанням та якістю навчальних досягнень. Досягнути таких цілей дозволяє ефективне управління дистанційною самостійною роботою студентів, зокрема, з використанням ресурсів інтернет-мереж.

Під управлінням самостійною роботою студентів розуміють діяльність викладача, спрямовану на формування в них нових знань, вироблення вмінь і навичок самостійної діяльності щодо планування та організації самостійної роботи, розробки технологій удосконалення й підвищення її продуктивності (Королюк, 2006).

Супроводження викладачем самостійної роботи студентів відбувається за такими напрямами:

- розробка дидактичних засобів, комплексу завдань для самостійної роботи, які відрізняються за рівнями складності, самостійності, характером діяльності;

- розробка критеріїв виконання запропонованих завдань;

- узгодження термінів виконання роботи й надання результатів;

- індивідуальне консультування за запитом студента;

- визначення вимог до оцінювання та рефлексії самостійної роботи (Бордонская та Голобкова, 2013).

Під час дистанційного навчання викладач виступає і тьютором, і модератором для студентів, він надає їм усю необхідну інформацію щодо організації діяльності, за потреби консультує, координує й контролює навчальний процес. Як тьютор викладач співпрацює з кожним студентом (студент розв'язує завдання самостійно), супроводжує його навчальну та дослідницьку діяльність, сприяє особистісному зростанню; як модератор він управляє власною діяльністю студентів у процесі розв'язування задач.

Такі ролі викладача та студента («навчаюсь сам») підвищують значущість самостійної роботи, а гнучкість, модульність, асинхронність та широкий доступ до різних джерел інформації забезпечують особистісну зорієнтованість дистанційного навчання й урахування індивідуальнопсихологічних особливостей студентів.

Пізнавальна діяльність, заснована на самоосвіті й організована засобами дистанційного навчання, надає викладачу широкі можливості щодо її організації.

Під самостійною роботою студентів під час вивчення математичних дисциплін в умовах дистанційного навчання будемо розуміти їх самостійну діяльність, спрямовану на розвиток математичного мислення, засвоєння нових математичних знань, умінь і навичок, закріплення або вдосконалення вже наявних, що здійснюється у процесі педагогічного супроводу викладача або за власною ініціативою та передбачає обов'язковий контроль наявних результатів (Подошва, 2012). 
Самостійна пізнавальна діяльність виражається через усвідомлене сприйняття пояснень викладача або матеріалу підручника, осмислення отриманих знань та їх використання під час розв'язування практичних завдань (Чкана та Мартиненко, 2019).

Вивчення математичних дисциплін має свою специфіку, оскільки засвоєння математичних знань вимагає від студентів високого рівня самостійності навіть при класичній (лекційно-практичній) формі організації навчання. Це зумовлено логічністю та чіткістю математичної науки в цілому, притаманністю кожній математичній дисципліні власної абстрактної математичної мови з досить великою кількістю символів.

Організація самостійної роботи майбутніх учителів фізикоматематичних спеціальностей різних курсів під час вивчення математичних дисциплін має істотні відмінності, але вона повинна відбуватися у відповідності до загальної логіки формування математичної компетентності студентів.

Планування й організація самостійної роботи студентів, особливо першокурсників, під час вивчення математичних дисциплін повинні враховувати такі фактори:

1) високий ступінь абстракції теоретичного матеріалу та наявність у ньому специфічної символіки;

2) низький рівень сформованості основних мисленнєвих дій: аналізу, синтезу, порівняння, узагальнення тощо;

3) наявність умінь коректно окреслювати математичну проблему, вибирати для неї правильний оптимальний метод розв'язування, грамотно описувати математичні операції процесу розв'язування.

Аналіз здатності студентів різних курсів самостійно працювати 3 інформацією підтверджує, що для першокурсників цей відсоток становить не більше 40, а педагогічного супроводу викладача під час самостійного виконання завдань потребують 75 відсотків.

Правильна організація самостійної роботи при дистанційному навчанні робить сам процес навчання неперервним, а технології дистанційного навчання спонукають студентів до активної діяльності на основі діючого алгоритму взаємодії всіх учасників навчального процесу, який до того ж дозволяє врахувати індивідуальні особливості кожного.

Управління самостійною роботою студентів в умовах дистанційного навчання під час вивчення математичного аналізу студентами фізикоматематичного факультету ефективно може бути організовано через використання електронної версії робочого зошита з курсу. Цей дидактичний засіб забезпечує послідовне й системне формування розумової діяльності студентів із засвоєння навчального матеріалу з курсу математичного аналізу.

Електронна версія робочого зошита $\epsilon$ помічником у процесі опрацювання теоретичного матеріалу й визначення орієнтовної системи 
дій студентів під час виконання практичних завдань, що відповідають різним дидактичним цілям та рівням самостійності.

На початку робочого зошиту пропонується технологічна карта вивчення дисципліни з зазначенням всіх видів практичної діяльності та термінів виконання завдань у дистанційному режимі.

Матеріал зошиту відповідає робочій програмі курсу, він структурований за темами. До кожної теми пропонується теоретичний матеріал (лекція) та пояснення до розв'язування типових завдань. Самостійна робота з ії засвоєння відповідає трьом рівням складності (репродуктивному, продуктивному, творчому), що дозволяє поділити ії завдання на три блоки. Блок 1 включає завдання на первинне закріплення навчального матеріалу, засвоєння або формулювання термінів та понять; у другому блоці подані завдання на виконання практичної роботи, розв'язування типових задач; розвивальні та творчі завдання, для виконання яких необхідне знання матеріалу даної теми та суміжних із нею, запропоновані у блоці 3 .

Блок 1 містить теоретичну та практичну частини, питання його теоретичної частини спрямовані на засвоєння означень понять, важливих тверджень або їх структурних складових, на виявлення та усвідомлення взаємозв'язків і відповідностей між ними; практичні завдання розраховані на глибше розуміння прикладної спрямованості цього теоретичного матеріалу.

Під час виконання завдань другого блоку, серед яких $€$ і завдання прикладного змісту, студенти напрацьовують певні вміння та формують компетенції. Більш творчий характер носять завдання третього блоку. Розв'язування цих завдань потребує використання або власного розумового потенціалу, або пошуку інформаційних джерел, які б допомогли в цьому, і дозволяє виділити студентів із високим рівнем засвоєння навчального матеріалу.

Важливою складовою організації самостійної роботи під час дистанційного навчання $€$ перевірка результатів ії виконання, яка може здійснюватися в режимі онлайн або оффлайн. Це можна робити з використанням різних технологій: організацію діалогу через соціальні мережі, месенджери, електронну пошту, телеконференції (синхронні чи асинхронні), створення тематичних веб-сторінок та веб-квестів на основі використання html-редакторів, ftp, web-браузерів, графічних редакторів тощо.

Усі виконані роботи у вигляді текстових, фото- та відеофайлів, презентацій, плакатів, графіків, схем тощо студенти розміщують на платформі дистанційного навчання або в інших засобах спілкування відповідно до зазначених термінів. Викладач перевіряє надані звіти, коментує й оцінює виконання завдань, супроводжує навчальну діяльність студентів.

Висновки та перспективи подальших наукових досліджень. Електронна версія робочого зошита $\epsilon$ доцільним і досить ефективним 
дидактичним засобом управління самостійною роботою студентів у процесі вивчення математичного аналізу в умовах дистанційного навчання. Його використання надає можливість кожному студенту працювати за певною системою й бути успішним; засвоювати навчальний матеріал у власному темпі, уникати пропусків занять, мати персональний педагогічний супровід викладача, одночасно працювати з різними джерелами інформації.

Подальші дослідження різних аспектів дистанційного навчання зумовлюють удосконалення вже наявних і пошук нових форм управління самостійною роботою студентів фізико-математичних факультетів педагогічних 3 ВО під час вивчення математичних дисциплін у віртуальному навчальному середовищі.

\section{ЛITЕРАТУРА}

Назарко, І.С. (2016). Використання засобів дистанційної освіти для підвищення ефективності навчального процесу у ВН3. Інноваційні технології в процесі підготовки фрахівців. Матеріали Міжнародної науково-практичної інтернетконфреренції 03-04 квітня 2016 року: збірник наукових праць. Вінниця (Nazarko, I. S. (2106). The use of distance education means to improve educational process in higher education institutions. Innovative technologies in the process of training specialists. Proceedings of the International Scientific and Practical Internet Conference April 3-04, 2016: a collection of scientific papers. Vinnytsia.)

Демонстрація можливостей Мoodle. Режим доступу: http://moodle.co.ua/course/view.php?id=2 (Demonstration of Moodle capabilities. Retrieved from: http://moodle.co.ua/course/view. php?id=2).

Рошаль, С. С., Семенова, Т. Ю. (2004). Самостоятельная работа студента в условиях дистанционного обучения: методические рекомендации. М.: СгA (Roshal, S. S., Semenova, T. Yu. (2004). Independent work of the student in the conditions of distance learning: methodical recommendations. M oscow).

Мартиненко, О. В., Чкана, Я. О. (2017). Використання робочого зошиту при організації самостійної роботи майбутніх учителів математики. Матеріали міжнародної науково-практичної конференції «Проблеми математичної освіти», сс. 133-134 (Martynenko, O. V., Chkana, Ya. O. (2017). The use of a workbook in the organization of independent work of future teachers of mathematics. Proceedings of the international scientific-practical conference "Problems of mathematical education", pp. 133-134).

Королюк, О. М. (2006). Управління самостійною роботою студентів коледжу в процесі вивчення природничо-математичних дисциплін. Неперервана професійна освіта: теорія і практика, Buп. 1-2, 78-84 (Koroliuk, O. M. (2006). Management of independent work of college students in the process of studying natural sciences and mathematics. Continuing professional education: theory and practice, 1-2, 78-84).

Бордонская, Л. А., Голобкова, Г. И. (2013). Рабочая тетрадь студента современного вуза как многофункциональное дидактическое средство. Ученые записки ЗабГУ, 5 (53), 51-66 (Bordonska, L. A., Golobkova, G. I. (2013). Workbook of a student of a modern university as a multifunctional didactic tool. Scientific notes of Transbaikal State University, 5 (53), 51-66).

Подошва, Н. В. (2012). Интенсификация самостоятельной работы студентов при обучении курсу высшей математики (автореф. дис. ... д-ра пед. наук: 13.00.02). Москва (Podoshva, N. V. (2012). Intensification of independent work of students in the course of higher mathematics (DSc thesis abstract). M oscow). 
Чкана, Я. О., Мартиненко, О. В. (2019). Математична компетентність учителів математики і фозики та особливості ії формування у процесі фахової підготовки. Суми (Martynenko, O.V., Chkana Ya.O. (2019). Mathematical competence of teachers of mathematics and physics and features of its formation in the process of professional training. Sumy).

\section{PEЗЮME}

Мартыненко Елена, Чкана Ярослав, Удовиченко Ольга. Управление самостоятельной работой будущих учителей математики в виртуальной обучающей среде через использование электронной версии рабочей тетради.

В статье рассмотрены вопросы управления самостоятельной работой студентов при дистанционном обучении студентов фризико-математических факультетов педагогических университетов. Уточнено понятие самостоятельной работы студентов при дистанционном обучении. Выделены особенности математических дисциплин, которые влияют на планирование и организацию самостоятельной работы студентов. Предложено использование электронной версии рабочей тетради по математическому анализу для обеспечения самостоятельной работы студентов в информационно-образовательной среде университета, показана целесообразность и эффрективность работы за ним.

Ключевые слова: самостоятельная работа студентов, дистанционное обучение, электронная версия рабочей тетради, математические дисциплины.

\section{SUMMARY}

Martynenko Olena, Chkana Yaroslav, Udoyydhenko Olga. The Management of independent work of future mathematics teachers in a virtual learning environment through the use of a workbook in the electronic version.

The actual direction of pedagogical theories is research of the students' independent work management process at the informational-educational environment through distance learning. The requirements to modern approach to the learning process are supposed a revision of approaches to the selection and updating forms of independent work, the didactic tools and their content, as well as appropriate technological support.

The goal of the article is to study management of the independent work by students in the process of distance learning of fundamental mathematical disciplines, by future mathematics teachers at pedagogical universities through the use of a workbook in the electronic version.

To solving the set tasks were used the next research methods: theoretical - analysis of the psychological-pedagogical, scientific-methodological, mathematical and educational literature, dissertations from the organization and study management of independent work by students in distance learning, at the methods of mathematics teaching; empirical - analysis and experience generalization of organizing independent students' work, monitoring of the progress of the initial process, questionnaires, analysis of the results from students' independent work in teaching mathematical disciplines.

The article clarifies the concept of students' independent work in distance learning, covers the features of mathematical disciplines that had influenced the process of planning and organization of students' independent work. The efficiency of using a workbook in an electronic version at mathematical analysis to ensure students' independent work in the informationaleducational environment at the university is proved. The use of an electronic version of the workbook allows each student to work according to a certain system and be successful; to master educational material at one's own pace, to avoid skipping classes, to have personal pedagogical support of the teacher, to work with different sources of information at the same time.

Key words: independent work of students, distance learning, electronic version of the workbook, mathematical disciplines. 